\title{
Sprawozdanie
}

\section{Ogólnopolska Konferencja Naukowa Kierunki zmian w prawie wyborczym, Olsztyn, 12 maja 2014 r.}

W dniu 12 maja 2014 r. na Wydziale Prawa i Administracji Uniwersytetu Warmińsko-Mazurskiego w Olsztynie pracownicy Katedry Prawa Konstytucyjnego zorganizowali Ogólnopolską Konferencję Naukową „Kierunki zmian w prawie wyborczym”. Patronat honorowy nad konferencją objął przewodniczący Państwowej Komisji Wyborczej Stefan Jaworski, sędzia Trybunału Konstytucyjnego w stanie spoczynku.

Konferencję otworzyła dr hab. Dorota Lis-Staranowicz, kierownik Katedry Prawa Konstytucyjnego WPiA UWM w Olsztynie, która powitała uczestników, a następnie przekazała głos przewodniczącemu PKW S. Jaworskiemu. Przewodniczący PKW podziękował za zorganizowanie konferencji oraz jej interesującą tematykę. Wskazał na potrzebę popularyzacji prawa wyborczego i podniesienia jego znaczenia w systemie prawa. Następnie głos zabrał Prodziekan ds. Studiów Stacjonarnych dr hab. Piotr Krajewski, prof. UWM. Prodziekan podkreślił, iż w konferencji biorą udział znamienici goście. Podziękował wszystkim za przyjazd i wyraził zadowolenie z obecności studentów.

Przewodnictwo w pierwszym panelu objął prof. dr hab. Andrzej Sokala (Centrum Studiów wyborczych UMK). Prof. A. Sokala nawiązując do wystąpienia dr. hab. P. Krajewskiego, nadmienił, że w niniejszej konferencji niewątpliwie uczestniczy „ekstraklasa” polskiego prawa wyborczego. Pierwszy 
referat pt. „Minimalny niezbędny zakres zmian w konstytucyjnej regulacji problematyki wyborczej” przedstawił prof. dr hab. Krzysztof Skotnicki (Uniwersytet Łódzki). Prelegent wyróżnił cztery najważniejsze kwestie, które powinny zostać uregulowane w Konstytucji RP. Pierwsza z nich dotyczy potrzeby zawarcia w ustawie zasadniczej przepisów regulujących wybory do Parlamentu Europejskiego. Druga odnosi się do uczestnictwa w wyborach nieobywateli. Trzecia kwestia dotyczy koniecznych zmian w zakresie praw wyborczych osób ubezwłasnowolnionych. Czwarty postulat prelegenta odnosił się do ujęcia w konstytucyjne ramy Państwowej Komisji Wyborczej i określenia jej kompetencji w zakresie stanowienia prawa. Kończąc wystąpienie, prof. K. Skotnicki zwrócił również uwagę na zbyt lakoniczne uregulowanie w Konstytucji RP trybu wyboru senatorów.

Drugi referat wygłosił prof. dr hab. Arkadiusz Żukowski (Uniwersytet Warmińsko-Mazurski). Wystąpienie dotyczyło światowych trendów zmian w prawie wyborczym. Prelegent odniósł się do dwóch problemów: poszerzania powszechności wyborów oraz zwiększania frekwencji wyborczej. Należy oczekiwać obniżenia granicy wieku pozwalającej na udział w elekcji z 18 do 16 lat. Pojawia się także postulat zrównania wieku czynnego i biernego prawa wyborczego i ustanowienia go na poziomie 18 lat (również w wyborach prezydenckich). Wzrasta tendencja do uwzględniania reprezentacji politycznej różnych grup społecznych, np. kobiet, mniejszości narodowych, religijnych, seksualnych. Metody głosowania poszerza się o tzw. alternatywne sposoby głosowania, które pozwalają w większym stopniu zapewnić powszechność wyborów oraz przyczyniają się do wzrostu frekwencji wyborczej. W celu zwiększenia partycypacji wyborczej obywateli wprowadza się także przymus wyborczy. W odniesieniu do formuły wyborczej prof. A. Żukowski stwierdził, iż coraz częściej wprowadza się mieszany system wyborczy łączący w sobie formułę proporcjonalną i większościową.

Wystąpienie dr. hab. Piotra Uziębły (Uniwersytet Gdański) dotyczyło propozycji nowelizacji kodeksu wyborczego w latach 2011-2014. Prelegent wskazał, że w tej kadencji Sejmu złożono 18 projektów zmian prawa wyborczego. Następnie krótko scharakteryzował zarówno przyjęte, jak i odrzucone projekty. Przyjęte nowelizacje miały na ogół charakter porządkujący i były prawie jednogłośnie przyjęte. Dr hab. P. Uziębło zwrócił uwagę na brak nadrzędnej idei w projektach zmian. Często dane ugrupowanie po- 
piera wprowadzenie określonej nowelizacji, gdyż może ona przynieść korzyści polityczne. Prelegent podkreślił, że potrzebne są ponadpartyjne zmiany prawa wyborczego.

Dr hab. Agnieszka Bień-Kacała przedstawiła referat pt. „Państwowa Komisja Wyborcza a system źródeł prawa”. Prelegentka wskazała, iż PKW stanowi stały, najwyższy organ wyborczy cechujący się autonomią i niezależnością. Charakter prawny tego organu nie został przez ustawodawcę określony. A. Bień-Kacała ukazała różnice między aktami prawa wewnętrznego a aktami prawa powszechnie obowiązującego. Wiążące wytyczne PKW mają często bardziej doniosły skutek niż akty prawa normatywnego. Referentka dostrzegła potrzebę uregulowania PKW w Konstytucji RP jako organu władzy sądowniczej z kompetencją wydawania rozporządzeń.

Prof. dr hab. Dariusz Dudek (Katolicki Uniwersytet Lubelski) zaprezentował referat zatytułowany „Prawo wyborcze a odpowiedzialność parlamentarzysty”. Na początku wystąpienia prelegent poddał pod rozwagę, czy potrzebne są zmiany w Konstytucji RP, Kodeksie wyborczym czy też w obu aktach. Zdaniem prof. D. Dudka zmiany są pożądane i zasadne w obu obszarach. Prelegent zwrócił uwagę na koniunkturalne zmiany prawa wyborczego. Dostrzegł potrzebę zmiany art. 62, 99, 105 i 107 Konstytucji RP. Zgłosił postulat obowiązku niekaralności zarówno w odniesieniu do biernego, jak i czynnego prawa wyborczego. Prof. D. Dudek zaproponował również zniesienie immunitetu formalnego.

Po przedstawieniu referatu przez prof. D. Dudka przewodniczący A. Sokala rozpoczął dyskusję. Głos zabrał ks. prof. dr hab. Ryszard Sztychmiler (Uniwersytet Warmińsko-Mazurski). Podziękował prof. D. Dudkowi za wystąpienie, wskazał na kwestię prawidłowej legislacji, potrzebę zaktywizowania społeczeństwa oraz rozliczania polityków. Dr hab. D. Lis-Staranowicz wyraziła obawę, iż w sytuacji trwających prac nad jednolitą ordynacją wyborczą do Parlamentu Europejskiego uregulowanie wyborów do tej instytucji w Konstytucji RP może okazać się przedwczesne. S. Jaworski zwrócił uwagę na problem w realizacji obowiązku współdziałania władz, z którym często musi borykać się PKW. Prof. A. Sokala stwierdził, że prace unijne trwają długo i nie można zwlekać z konstytucyjną regulacją wyborów do PE.

Drugi panel poprowadził dr Marcin Dąbrowski (Uniwersytet Warmińsko-Mazurski). Pierwszy referat $\mathrm{w}$ tej części konferencji wygłosi- 
ła prof. dr hab. A. Młynarska-Sobaczewska (Instytut Nauk Prawnych Polskiej Akademii Nauk), która poruszyła problem legitymizacji i reprezentacji w jednomandatowych okregach wyborczych. Prelegentka przedstawiła podstawowe założenia systemów wyborczych $\mathrm{w}$ zakresie wyłaniania reprezentacji i realizacji preferencji wyborczych oraz zaprezentowała koncepcje środkowego wyborcy, zgodnie $\mathrm{z}$ którą - w znaczym uproszczeniu wygrywa wybory ten, kto przekona do siebie umiarkowane i najliczniejsze grupy elektoratu. $\mathrm{W}$ jednomandatowym okręgu wyborczym największe szanse na wygraną ma kandydat, który przekona do siebie umiarkowany elektorat. Zdaniem prof. A. Młynarskiej-Sobaczewskiej wybory większościowe w formule jednomandatowej, w szczególności na szczeblu lokalnym, mogą w pewnej perspektywie odwrócić tendencję upartyjnienia samorządu.

Dr Jarosław Zbieranek (Biuro Rzecznika Praw Obywatelskich) przedstawił referat pt. „Głosowanie wyborców niepełnosprawnych i w zaawansowanym wieku - wybrane problemy". Prelegent pozytywnie ocenił pakiet ułatwień wprowadzonych do Kodeksu wyborczego, tzw. alternatywnych sposobów głosowania. Wskazał jednak na nieskuteczność ww. mechanizmów z uwagi na fakt, iż wyborcy na ogół nie znają swoich praw w tym zakresie. Zdaniem J. Zbieranka wyborcy powinni być indywidualnie zawiadamiani o wyborach i informowani o istniejących ułatwieniach.

Wystąpienie dr Joanny Juchniewicz (Uniwersytet Warmińsko-Mazurski) dotyczyło wybranych problemów finansowania kampanii wyborczych. Prelegentka poruszyła kwestię wydatkowania środków na kampanię wyborczą. Dr J. Juchniewicz zwróciła uwagę na potrzebę zapewnienia równości komitetom wyborczym oraz zakaz wielkopowierzchniowych reklam i wyrok TK w tym zakresie.

Dr Monika Giżyńska (Uniwersytet Warmińsko-Mazurski) przedstawiła referat zatytułowany „Przymus wyborczy - panaceum na niską frekwencję”. Prelegentka poddała pod rozwagę, czy prawo do udziału w wyborach stanowi uprawnienie, czy też obowiązek wyborcy. Stwierdziła, iż więcej argumentów przemawia na rzecz obowiązku. Dr M. Giżyńska uznała wprowadzenie przymusu wyborczego za uzasadnione i celowe.

Dr Andrzej Jackiewicz (Uniwersytet w Białymstoku) zaprezentował referat pt. „Wpływ terminu wyborów do Parlamentu Europejskiego na frekwencję wyborczą - zarys problematyki”. Zdaniem prelegenta dzień tygodnia, 
w którym przeprowadzane są wybory, zależy od specyfiki danego państwa. Wybory do PE należą do kategorii second order election. Cieszą się mniejszym zainteresowaniem wyborców niż wybory do parlamentu krajowego. Według dr. A. Jackiewicza na wzrost frekwencji w elekcji do PE pozytywnie wpłynęłyby wybory dwudniowe.

Dr J. Zbieranek w prezentacji zatytułowanej „Polacy o prawie wyborczym i mechanizmach kampanii wyborczej” przedstawił wyniki wspólnych badań CSW UMK w Toruniu i Centrum Badania Opinii Społecznej.

Po wystąpieniu dr. J. Zbieranka przewodniczący drugiego panelu dr Marcin Dąbrowski otworzył dyskusję. Przewodniczący PKW S. Jaworski wskazał, że zmiany w prawie wyborczym powinny być przemyślane i ostrożne. Najwięcej kontrowersji wywołała kwestia przymusu wyborczego. Dr hab. P. Uziębło wyraził wątpliwość, czy powinno się edukować obywateli przez nakładanie obowiązku. Istnieje prawdopodobieństwo, iż wyborcy zobligowani do udania się na wybory zagłosują „dla żartu” na niepoważne ugrupowania albo ich głosy będą dodatkową "premią" partii zwycięskiej. Dr M. Giżyńska zwróciła uwagę, iż obowiązek wyborczy może sprawić, że obywatele zaczną interesować się programami partii. Prof. A. Młynarska-Sobaczewska przestrzegła przed fetyszyzacją frekwencji wyborczej, wskazując, że ważniejsze jest świadome oddanie głosu przez wyborcę.

Konferencję zakończyła dr hab. D. Lis-Staranowicz, dziękując wszystkim uczestnikom. Referaty i dyskusja potwierdziły trafność wyboru tematu konferencji „Kierunki zmian w prawie wyborczym”. Dr hab. D. Lis-Staranowicz podkreśliła, iż temat ten jest jak najbardziej aktualny, ale wydaje się, że będzie aktualny także jutro i można się spodziewać, że nie straci nic na swojej świeżości również za dziesięć lat.

Dawid Daniluk Uniwersytet Warmińsko-Mazurski w Olsztynie 